\title{
Evaluation of Composted Cattle Manure Rate on Bulb Onion Grown with Reduced Rates of Chemical Fertilizer
}

\author{
Jongtae Lee ${ }^{1}$
}

ADDITIONAL INDEX WORDs. sustainable agriculture, Allium cepa, soil organic matter, onion bulb yield

SuMMARY. A field experiment was conducted to evaluate yield performance and soil fertility of onion (Allium cepa) grown with beef cattle manure compost (CMC) under a reduced rate of chemical fertilizer for sustainable production in the 200607 growing season. Chemical fertilizer application rate was reduced to a third of the recommended rate of nitrogen $(\mathrm{N})$, phosphorus $(\mathrm{P})$, and potassium $(\mathrm{K})$. Treatments consisted of five levels of CMC $\left(0,20,40,60\right.$, and $\left.80 \mathrm{Mg} \cdot \mathrm{ha}^{-1}\right)$. There was a significant increasing effect on growth and yield parameters by applying CMC compared with $0 \mathrm{Mg} \cdot \mathrm{ha}^{-1}$. In addition, there was also a significant increasing quadratic effect on yield on increasing CMC rates from 0 to $80 \mathrm{Mg} \cdot \mathrm{ha}^{-1}$ with an $R^{2}$ of 0.46. Maximum marketable yield was $62.7 \mathrm{Mg} \cdot \mathrm{ha}^{-1}$ at $40 \mathrm{Mg} \cdot \mathrm{ha}^{-1} \mathrm{CMC}$, which was due to increased stand reduction and unmarketable bulbs as well as decreased bulb weight at higher rates of CMC. The CMC rates had no effect on bulb dry weight and $\mathbf{N}$ or $\mathbf{P}$ concentration in the bulb and leaf. Furthermore, there was an increasing linear effect on soil $\mathrm{pH}$, and organic matter $(\mathrm{OM})$, available $\mathrm{P}$, and exchangeable cations throughout vegetative growth and at harvest. We concluded that the excessive application of CMC did not affect onion yield and accumulated soil fertility.

$\mathrm{O}$ nion fertility has been an important subject with regards to onion productivity worldwide. In particular, onion has a shallow branched root system with most roots in the top $30 \mathrm{~cm}$ of soil (Portas, 1973; Weaver and Brunner, 1927). Characteristically, such a root system leads to the low density of roots in onion. This shallow root system means onion requires more fertilizer to produce the crop (Brewster, 2008; Greenwood et al., 1982).

For sustainable crop production, pesticides and herbicides are not allowed and application rates of mineral fertilizers are restricted legally in Korea. N, P, and $\mathrm{K}$ application rates for onion production are recommended as 240,34 , and $128 \mathrm{~kg} \cdot \mathrm{ha}^{-1}$, respectively, where $67 \%$ of $\mathrm{N}$ and $60 \%$ of $\mathrm{K}$ fertilizer are applied in two split sidedressings [Rural Development Administration (RDA, 2006)]. In addition, the quantity of mineral fertilizer should be reduced to a third based on the recommended rates of $\mathrm{N}, \mathrm{P}$, and $\mathrm{K}$ to produce certified products without agricultural chemicals. Thus, nutrient management for

Onion Research Institute, Gyeongnam Agricultural Research and Extension Services, Changnyeong 635821 , Republic of Korea

${ }^{1}$ Corresponding author. E-mail: organicjt@hotmail.com. sustainable crop production depends on compost from animal manures or organic fertilizers. Compost can serve as an alternative to mineral fertilizers for improving soil structure (Dauda et al., 2008) and microbial biomass (Suresh et al., 2004). The rate, timing, and technique of application can be controlled by the grower; however, compost quality can vary considerably within the same source and different sources at various times of the year (Gaskell and Smith, 2007). Gaskell and Smith (2007) stated that the $\mathrm{N}$ availability from compost to the succeeding crop was variable, ranging from negative to low $\mathrm{N}$ recovery rates of $4 \%$ to $15 \%$, to a high rate of $57 \%$. Wallace (2006) developed guidelines for using the carbon to $\mathrm{N}(\mathrm{C}: \mathrm{N})$ ratio of the compost to determine its availability.

Moreover, the response of onion crops to manure depends on $\mathrm{N}$ availability for crop growth. $\mathrm{N}$ availability from manure varies greatly depending on the type of animal, type and amount of bedding, and age and storage conditions of the manure (Bary et al., 2000). Characterization of chemical constituents for inputs of the manure may help predict intermediate-term mineralization rates (Palm et al., 2001). However, the process may vary with weather conditions such as rainfall and temperature (Rosen and Allen, 2007). Long-term manure application based on $\mathrm{N}$ can result in the accumulation of other nutrients such as $\mathrm{P}$ and $\mathrm{K}$ in soil and eventually reach excessive levels (Bary et al., 2000). Further, over applying manure may also increase the risk of contaminating surface or groundwater with $\mathrm{P}$ (Biberacher et al., 2009).

Yield response to compost is greater in soils with low fertility, but response varies depending on the compost source (Gallardo-Lara and Nogales, 1987). When onion plants were grown in plots of sandy loam soil, compost applied over a two-year period at cumulative totals of $37 \mathrm{Mg} \cdot \mathrm{ha}^{-1}$ increased marketable yield (Bevacqua and Mellano, 1993). There was a significant linear effect on total onion yield with increasing fresh poultry litter applications from 0 to $22 \mathrm{Mg} \cdot \mathrm{ha}^{-1}$ (Boyhan et al., 2010). However, onion yield response to animal manure or compost rates was not always positive (Abdelrazzag, 2002; Gambo et al., 2008). Vidigal et al. (2010) reported that the application of $43 \mathrm{Mg} \cdot \mathrm{ha}^{-1}$ swine compost resulted in onion bulbs with greater size and higher marketable yield.

\begin{tabular}{lllc}
\hline $\begin{array}{l}\text { Units } \\
\text { To convert U.S. to SI, } \\
\text { multiply by }\end{array}$ & U.S. unit & SI unit & $\begin{array}{l}\text { To convert SI to U.S., } \\
\text { multiply by }\end{array}$ \\
\hline 0.3048 & $\mathrm{ft}$ & $\mathrm{m}$ & 3.2808 \\
0.0929 & $\mathrm{ft}^{2}$ & $\mathrm{~m}^{2}$ & 10.7639 \\
2.54 & inch $(\mathrm{es})$ & $\mathrm{cm}$ & 0.3937 \\
25.4 & inch $(\mathrm{es})$ & $\mathrm{mm}$ & 0.0394 \\
1.1209 & $\mathrm{lb} / \mathrm{acre}$ & $\mathrm{kg} \cdot \mathrm{ha}^{-1}$ & 0.8922 \\
1 & meq/100 g & $\mathrm{cmol} \cdot \mathrm{kg}^{-1}$ & 1 \\
28.3495 & $\mathrm{oz}$ & $\mathrm{g}$ & 0.0353 \\
0.001 & $\mathrm{ppm}$ & $\mathrm{g} \cdot \mathrm{kg}^{-1}$ & 1000 \\
1 & $\mathrm{ppm}$ & $\mathrm{mg} \cdot \mathrm{kg}^{-1}$ & 1 \\
2.2417 & ton $/ \mathrm{acre}$ & $\mathrm{Mg} \cdot \mathrm{ha}^{-1}$ & 0.4461 \\
$\left({ }^{\circ} \mathrm{F}-32\right) \div 1.8$ & ${ }^{\circ} \mathrm{F}$ & ${ }^{\circ} \mathrm{C}$ & $\left({ }^{\circ} \mathrm{C} \times 1.8\right)+32$
\end{tabular}


Although growers supporting sustainable agriculture have been trying to increase onion yield by increased compost application, the effect of compost may not be sufficient in the short term. The objective of this study was to evaluate the effect of composted beef manure on the yield of intermediateday onion and soil fertility under reduced chemical fertilization rates during short-term practices.

\section{Materials and methods}

Field eXPeriment. The present experiment was conducted at the Onion Research Institute's experimental farm, Changnyeong district, Korea (lat. $35^{\circ} 55^{\prime} \mathrm{N}$, long. $128^{\circ} 47^{\prime} \mathrm{E}$ ) during the 2006-07 seasons. The experimental site has been under continuous cultivation including rice (Oryza sativa) and onion. Top soil texture was silt loam with an OM content of $17.8 \mathrm{~g} \cdot \mathrm{kg}^{-1}, \mathrm{pH} 7.4,5.3 \mathrm{mg} \cdot \mathrm{kg}^{-1}$ residual nitrate nitrogen $\left(\mathrm{NO}_{3}-\mathrm{N}\right)$, $104 \mathrm{mg} \cdot \mathrm{kg}^{-1}$ available $\mathrm{P}$, and 0.50 $\mathrm{cmol} \cdot \mathrm{kg}^{-1}$ exchangeable K before planting. Seeds of 'Changnyeongsindaego' onion, an open-pollinated cultivar for fall transplanting, were sown on 8 Sept. 2006, and transplanted in seven rows on 8 Nov. 2006 at a spacing of $15 \mathrm{~cm}$ in-row and $20 \mathrm{~cm}$ between rows. Beds were mulched with a sheet of transparent polyethylene. The bed size was $12 \times 1.4 \mathrm{~m}$, accommodating 560 plants per plot.

Experimental Design. Treatments included CMC applied at rates of $0,20,40,60$, and $80 \mathrm{Mg} \cdot \mathrm{ha}^{-1}$ on a fresh weight basis. The composted cattle manure was obtained from a local compost producer. It included rice hull as bedding and was collected from a concrete floor and decomposed for about six months. Cattle manure compost sample analysis and nutrient rate applied at $20 \mathrm{Mg} \cdot \mathrm{ha}^{-1}$ are shown in Table 1.
Chemical fertilizer rates of $80 \mathrm{~kg} \cdot \mathrm{ha}^{-1} \mathrm{~N}, 11.4 \mathrm{~kg} \cdot \mathrm{ha}^{-1} \mathrm{P}$, and $42.5 \mathrm{~kg} \cdot \mathrm{ha}^{-1} \mathrm{~K}$ based on the recommended rates of $\mathrm{N}, \mathrm{P}$, and $\mathrm{K}$ were applied in all treatments (RDA, 2006). Compost, fused phosphate fertilizer $(\mathrm{P})$, one third of the urea $(\mathrm{N})$, and $40 \%$ of potassium sulfate (K) were applied preplant with the rest split into two equal applications in February and March. The experimental design was a randomized complete block with three replicates. Irrigation was performed once at transplanting, while weeding and other cultural practices were completed as necessary.

Sampling AND analysis. Onion height, number of leaves, bulb diameter, and fresh weight were measured on 4 Apr. [147 d after transplanting (DAT) ], 25 Apr. (165 DAT), 7 May (189 DAT), and 8 June (210 DAT) with 10 plants per replicate. The soil samples were collected for chemical analysis from the surface layer ( 0 $15 \mathrm{~cm}$ ) at the same time plant growth was measured and before fertilization. Harvesting was conducted after $80 \%$ of the tops had broken over at the neck on 8 June 2007. Onions were pulled from a $3.15 \mathrm{~m}^{2}(2.25 \times 1.4 \mathrm{~m})$ area per experimental unit and placed on top of the ground for $2 \mathrm{~d}$ before removing tops. They were individually weighed and their bulb diameters were determined. Damaged, diseased, bolted, and doubled onions were culled as unmarketable yield.

After measuring plant height (centimeters) and bulb diameter (millimeters), onion plants were separated into the bulb and green leaves, followed by measuring fresh leaf weight (grams/plant) and bulb weight (grams/plant) on an individual plot basis. The samples at harvest were dried to a constant weight at $70^{\circ} \mathrm{C}$. The dried samples were ground, weighed, and dissolved in hydrogen sulfate $\left(\mathrm{H}_{2} \mathrm{SO}_{4}\right)$ and hydrogen dioxide $\left(\mathrm{H}_{2} \mathrm{O}_{2}\right)$. Total $\mathrm{N}$ was measured by the Kjeldahl method. P was measured colorimetrically with an ammoniumvanadate-molybdate method (Gericke and Kurmies, 1952).

Air-dried soil samples were analyzed for $\mathrm{pH}$, electrical conductivity (EC), $\mathrm{OM}, \mathrm{NO}_{3}-\mathrm{N}$, available $\mathrm{P}$, and exchangeable K. Organic matter was determined by the Tyurin method (Schollenberger, 1927) and $\mathrm{NO}_{3}-\mathrm{N}$ content by reflectometry (RQ plus; Merck, Whitehouse Station, NJ). The Lancaster method (RDA, 2002) was used in determining available $\mathrm{P}$. An atomic absorption spectrophotometer was used to measure exchangeable cations. Soil $\mathrm{pH}$ and $\mathrm{EC}$ were measured by both an electrometer and a conductivity meter.

\section{Results and discussion}

Plant growth AND BULB YIELD. Data presented in Table 2 indicate the response of growth characters based on different rates of CMC. The number of leaves and bulb diameter increased with increasing CMC rates at the vegetative growth stage (147 and 165 DAT). However, during the late growth stage (189 DAT), only the number of leaves was affected by CMC rates.

An examination of the top, bulb, and root weight showed a quadratic function at 189 DAT (Table 3). Bulb weight showed a quadratic effect at 210 DAT as well. The quadratic equation for marketable yield was $y=$ $-32.748 x^{2}+298.26 x+5406.2$ and $R^{2}=0.46$ (Fig. 1). The derived value of this equation was $45.5 \mathrm{Mg} \cdot \mathrm{ha}^{-1}$ $\mathrm{CMC}$ and its maximum yield was $60.9 \mathrm{Mg} \cdot \mathrm{ha}^{-1}$. However, according to Fisher's protected least significant difference, maximum calculated yield

Table 1. Chemical properties of composted cattle manure compost on dry weight basis and nutrients applied by $20 \mathrm{Mg} \cdot \mathrm{ha}^{-1}$ (8.9 tons/acre) rate.

\begin{tabular}{|c|c|c|c|c|c|c|c|c|c|c|c|}
\hline & \multirow{2}{*}{$\begin{array}{c}\text { Moisture } \\
\text { content } \\
\left(\mathrm{g} \cdot \mathrm{kg}^{-1}\right)^{\mathrm{z}}\end{array}$} & $\begin{array}{c}\text { Organic } \\
\text { matter }\end{array}$ & $\mathbf{N}^{\mathrm{x}}$ & $\mathbf{P}$ & $\mathbf{K}$ & $\mathrm{Ca}$ & $\mathrm{Mg}$ & Ammonium-nitrogen & $\mathrm{NO}_{3}-\mathrm{N}$ & \multirow[b]{2}{*}{$\mathrm{pH} \mathrm{1:5}$} & \multirow{2}{*}{$\begin{array}{c}\mathrm{C}: \mathrm{N} \\
\text { (ratio) }\end{array}$} \\
\hline & & \multicolumn{6}{|c|}{$\left(\mathrm{g} \cdot \mathrm{kg}^{-1}\right)$} & $\left(\mathrm{mg} \cdot \mathrm{kg}^{-1}\right)^{\mathrm{z}}$ & & & \\
\hline Contents $^{\mathrm{y}}$ & 601 & 380.7 & 14.3 & 2.5 & 27.5 & 9.9 & 10.6 & 15.2 & $1,748.7$ & 8.2 & 15.5 \\
\hline $\begin{array}{l}\text { Nutrients } \\
\quad \text { applied }\left(\mathrm{kg} \cdot \mathrm{ha}^{-1}\right)^{\mathrm{z}}\end{array}$ & - & 3,040 & 115 & 20 & 220 & 79 & 85 & 0.12 & 13.95 & - & - \\
\hline
\end{tabular}


Table 2. Changes in number of onion leaves, plant height, and bulb diameter as affected by cattle manure compost rates.

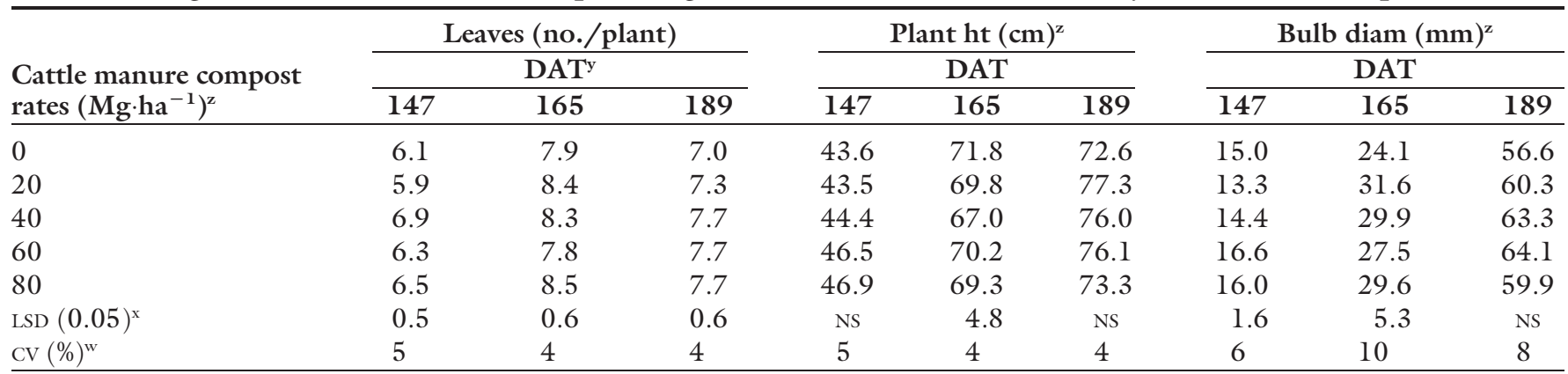

${ }^{\mathrm{z}} 1 \mathrm{Mg} \cdot \mathrm{ha}^{-1}=0.4461 \mathrm{ton} / \mathrm{acre}, \mathrm{l} \mathrm{cm}=0.3937 \mathrm{inch}, 1 \mathrm{~mm}=0.0394 \mathrm{inch}$.

y Days after transplanting.

xisher's protected least significant difference at $P \leq 0.05$.

${ }^{\mathrm{w}}$ Coefficient of variation.

Table 3. Changes in top, bulb, and root weights of onion on fresh basis as affected by cattle manure compost rates.

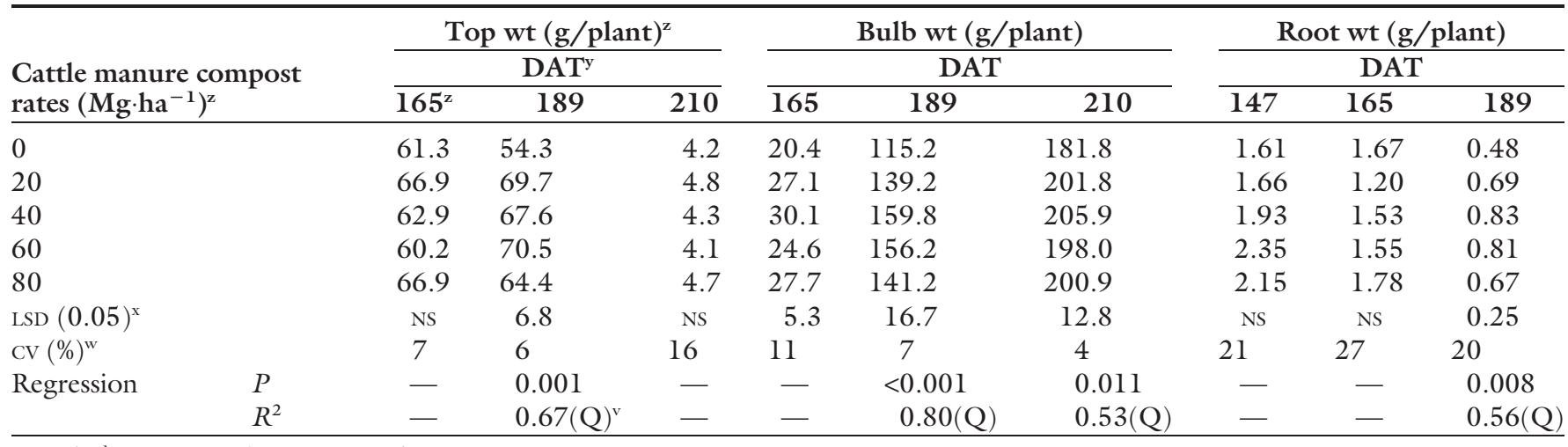

${ }^{\mathrm{z}} \mathrm{l} \mathrm{Mg} \cdot \mathrm{ha}^{-1}=0.4461 \mathrm{ton} / \mathrm{acre}, \mathrm{l} \mathrm{g}=0.0353 \mathrm{oz}$.

yDays after transplanting.

xFisher's protected least significant difference at $P \leq 0.05$.

${ }^{\mathrm{w}}$ Coefficient of variation.

${ }^{\mathrm{v}} \mathrm{Q}=$ quadratic.

does not differ from yields at 20 or $40 \mathrm{Mg} \cdot \mathrm{ha}^{-1} \mathrm{CMC}$. In addition, stand reduction was negatively affected by increasing CMC (Table 4). The CMC rate of $80 \mathrm{Mg} \cdot \mathrm{ha}^{-1}$ resulted in a significant increase in stand reduction compared with 20 or $40 \mathrm{Mg} \cdot \mathrm{ha}^{-1}(P \leq 0.05)$. This result was presumably because of an increased salt concentration at higher CMC rates. P uptake in onion bulb tissue was significantly higher at $40 \mathrm{Mg} \cdot \mathrm{ha}^{-1} \mathrm{CMC}$ than the control but did not increase with higher CMC rates. Furthermore, $\mathrm{N}$ levels in bulb and leaf tissue did not differ significantly over the range of CMC application rates.

For the production of organic short-day onion, there was a significant linear effect on total onion yield by increasing the application of poultry litter from 0 to $25 \mathrm{Mg} \cdot \mathrm{ha}^{-1}$ with an $R^{2}$ of 0.719 (Boyhan et al., 2010). The result might be due to the absence of chemical fertilizer application with organic onion production and high nutrient content $\left(32 \mathrm{~g} \cdot \mathrm{kg}^{-1} \mathrm{~N}, 23\right.$ $\left.\mathrm{g} \cdot \mathrm{kg}^{-1} \mathrm{P}, 26 \mathrm{~g} \cdot \mathrm{kg}^{-1} \mathrm{~K}\right)$ in the poultry litter used for onion production. Also, the authors mentioned that most growers had reported adequate yield response with a poultry litter application of 10-15 Mg.ha- ${ }^{-1}$. Even though compost or animal manure were effective at improving soil OM content and soil fertility, especially in regards to long-term applications (Haynes and Naidu, 1998; Prasad, 2009), the effectiveness of animal manure on bulb onion production was not always positive. According to Abdelrazzag (2002), increasing rates of chicken manure tended to reduce onion yield, and high sheep manure rates did not significantly enhance the yield either. Those results could be due to the harmful effect of increased EC because of manure application. Gambo et al. (2008) reported that increasing rates of farmyard manure did not have significantly positive effects on onion bulb yield. Also, in an organic system trial with five rates of organic compost (0-60 $\left.\mathrm{Mg} \cdot \mathrm{ha}^{-1}\right)$, the calculated maximum yield of marketable bulbs was obtained with $43.4 \mathrm{Mg} \cdot \mathrm{ha}^{-1}$ of swine manure (Vidigal et al., 2010). Similarly, the onion bulb yield was not significantly influenced by gamma-irradiated sewage sludge or farmyard manure rates of 5,10 , and $15 \mathrm{Mg} \cdot \mathrm{ha}^{-1}$ (Rathod et al., 2008).

According to Sullivan et al. (2001), in the Pacific northwestern United States, manure or compost application before seeding onion was not recommended because salts from manure or compost might reduce seed germination and increase water stress. Last, the transplanted onion in our research showed a significantly higher stand reduction at $80 \mathrm{Mg} \cdot \mathrm{ha}^{-1}$ than at $40 \mathrm{Mg} \cdot \mathrm{ha}^{-1}$ of manure. 
SoIl CHEMical PROPERTIEs. The $\mathrm{OM}$ and available $\mathrm{P}$ content were significantly affected by increasing CMC rates at both 147 and 210 DAT (Table 5). Manure rates had a linear effect on soil nutrients, P, and $\mathrm{K}$ at the vegetative growth stage (147 DAT). However, $\mathrm{NO}_{3}-\mathrm{N}$ content was not significantly different among treatments.

Nitrate- $\mathrm{N}$ availability is highly variable. Also, $\mathrm{N}$ mineralization is dynamic based on soil conditions. The release or immobilization of $\mathrm{N}$ from compost depends on compost quality, such as age, stability, and feedstock used (Prasad, 2009). The estimated percent of total $\mathrm{N}$ that is potentially mineralized after application depends on the compost C:N ratio (Wallace, 2006). According to this assumption, a $\mathrm{C}: \mathrm{N}$ ratio of 15.0 , which is equivalent to that of CMC in our study, could produce a mineralized $\mathrm{N}$ rate of $10 \%$ or less from organic $\mathrm{N}$ in the first year. The very low mineralization of $\mathrm{N}$ was observed in our study, which had low soil $\mathrm{NO}_{3}-\mathrm{N}$ content at the vegetative stage. This may be a result of the higher $\mathrm{N}$ consumption by microorganisms during manure decomposition in soil than $\mathrm{N}$ released from manure during the vegetative growth stage. In addition, soil available $\mathrm{P}$ and exchangeable $\mathrm{K}$ were linearly affected by increasing CMC application with an $R^{2}$ of 0.37 and 0.54 , respectively, at the vegetative

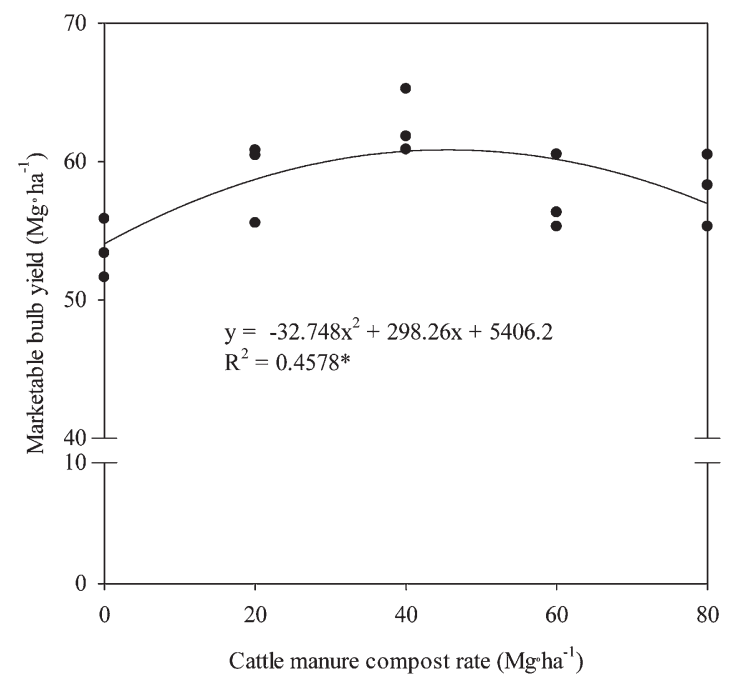

Fig. 1. Marketable onion bulb yield response to cattle manure compost rates with quadratic curve, regression equation and $\mathrm{R}^{2}$ values ( ${ }^{*}$ represents $P<0.05$ ); $1 \mathrm{Mg} \cdot \mathrm{ha}^{-1}=0.4461$ ton/acre.

growth stage. P deficient onion appears stunted and develops slowly. Normally, onion is affected by P during the early growth stages since root systems are limited and cool soil temperature reduces $\mathrm{P}$ diffusion or movement to root surfaces (Brown, 2000). However, the effectiveness of $\mathrm{P}$ application in soil was not always evident (Al-Moshileh, 2001; Boyhan, 2007; Lee et al., 2003). Onion generally absorbs equal amounts of $\mathrm{N}$ and $\mathrm{K}$ (Salo et al., 2002; Sullivan et al., 2001 ) and in some studies, more $\mathrm{K}$ than N (Lee, 2010; Lee et al., 2009). Nevertheless, the K fertilization efficiency on onion yields was inconsistent among studies. Onion bulb yield increased up to $84 \mathrm{~kg} \cdot \mathrm{ha}^{-1}$ (Boyhan, 2007), $190 \mathrm{~kg} \cdot \mathrm{ha}^{-1}$ (ElBassiony, 2006), $286 \mathrm{~kg} \cdot \mathrm{ha}^{-1}$ (El-Al et al., 2010). By contrast, there was zero effect of $\mathrm{K}$ in other studies on onion with rates of 0 or $150 \cdot \mathrm{kg} \mathrm{ha}^{-1}$ (Al-Moshileh, 2001; Lee et al., 2003), or 50 or $150 \mathrm{~kg} \cdot \mathrm{ha}^{-1}$ (Amin et al., 2007). This inconsistency might be due to either the difference in preplant $\mathrm{K}$ content or K sources from OM in the soil.

\section{Conclusions}

Cattle manure compost improved yield of intermediate-day onion and soil fertility under reduced rates of chemical fertilizer. However, CMC application over $40 \mathrm{Mg} \cdot \mathrm{ha}^{-1}$ did not increase onion bulb yield but accumulated soil nutrients. Further long-term studies should be carried out to clarify residual and beneficial effects from compost regarding crop and soil quality.

Table 4. Comparison of cattle manure compost rate effects on onion bulb yield, stand reduction, bulb dry matter, and tissue nutrient uptakes.

\begin{tabular}{|c|c|c|c|c|c|c|c|c|c|}
\hline \multirow{2}{*}{\multicolumn{2}{|c|}{$\begin{array}{l}\text { Cattle manure } \\
\text { rates }\left(\mathrm{Mg} \cdot \mathrm{ha}^{-1}\right)^{\mathrm{z}}\end{array}$}} & \multicolumn{2}{|c|}{ Yield $\left(\mathrm{Mg} \cdot \mathrm{ha}^{-1}\right)$} & \multirow{2}{*}{$\begin{array}{c}\text { Stand } \\
\text { reduction (\%) }\end{array}$} & \multirow{2}{*}{$\begin{array}{c}\text { Bulb dry } \\
\text { wt (\%) }\end{array}$} & \multicolumn{2}{|c|}{ Bulb $\left(\mathrm{kg} \cdot \mathrm{ha} \mathrm{a}^{-1}\right)^{\mathrm{y}}$} & \multicolumn{2}{|c|}{ Leaf $\left(\mathrm{kg} \cdot \mathrm{ha}^{-1}\right)$} \\
\hline & & Marketable & Unmarketable & & & $\mathbf{N}^{\mathrm{y}}$ & $P^{y}$ & $\mathbf{N}$ & $\mathbf{P}$ \\
\hline \multicolumn{2}{|l|}{0} & 53.6 & 0.27 & 3.8 & 9.5 & 49.3 & 9.4 & 9.2 & 0.9 \\
\hline \multicolumn{2}{|l|}{40} & 62.7 & 0.22 & 1.9 & 9.3 & 54.9 & 16.7 & 10.6 & 1.8 \\
\hline \multicolumn{2}{|l|}{60} & 57.4 & 0.25 & 3.8 & 9.3 & 66.6 & 12.7 & 9.2 & 1.0 \\
\hline \multicolumn{2}{|l|}{80} & 58.0 & 0.29 & 6.0 & 9.0 & 60.5 & 15.1 & 7.5 & 1.4 \\
\hline \multirow[t]{2}{*}{ Regression } & $P$ & 0.025 & - & 0.007 & - & 0.042 & 0.090 & - & - \\
\hline & $R^{2}$ & $0.46(\mathrm{Q})^{\mathrm{v}}$ & - & $0.57(\mathrm{Q})$ & - & $0.28(\mathrm{~L})^{\mathrm{v}}$ & $0.25(\mathrm{Q})$ & - & - \\
\hline
\end{tabular}

${ }^{\mathrm{z}} \mathrm{l} \mathrm{Mg} \cdot \mathrm{ha}^{-1}=0.4461$ ton/acre.

${ }^{\mathrm{N}} \mathrm{N}=$ nitrogen, $\mathrm{P}=$ phosphorus, $1 \mathrm{~kg} \cdot \mathrm{ha}^{-1}=0.8922 \mathrm{lb} /$ acre

${ }^{x}$ Fisher's protected least significant difference at $P \leq 0.05$.

"Coefficient of variation.

${ }^{\mathrm{v}} \mathrm{Q}=$ quadratic, $\mathrm{L}=$ linear. 


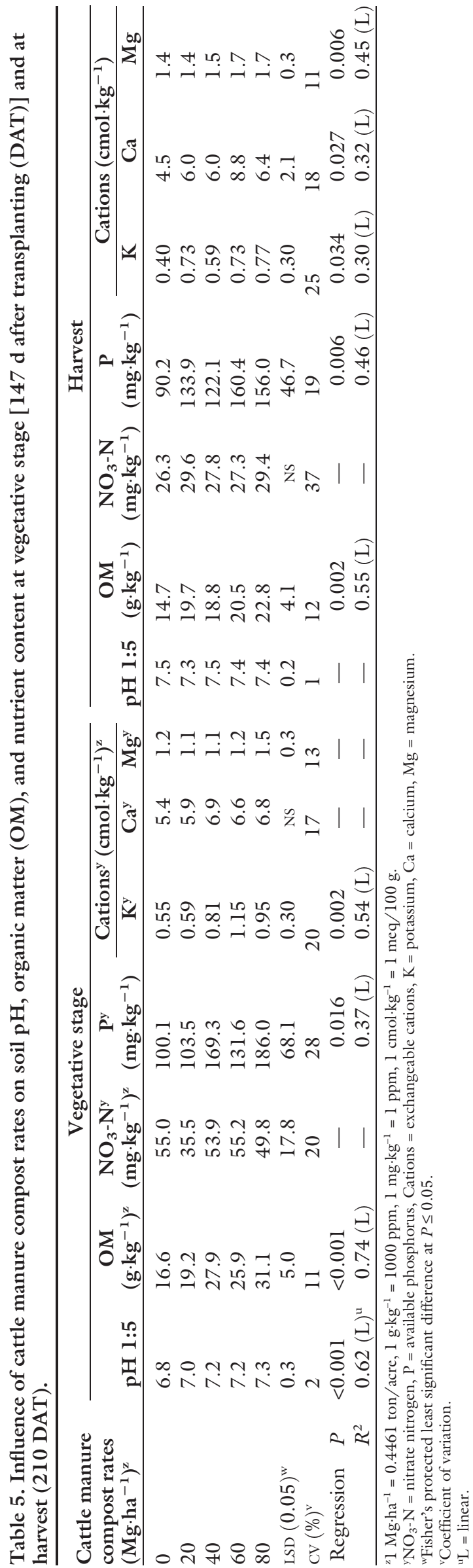

\section{Literature cited}

Abdelrazzag, A. 2002. Effect of chicken manure, sheep manure and inorganic fertilizer on yield and nutrients uptake by onion. Pak. J. Biol. Sci. 5: 266-268.

Al-Moshileh, A.M.P. 2001. Effect of nitrogen, phosphorus and potassium fertilizers on onion productivity in central region of Saudi Arabia. Assiut J. Agr. Sci. 32:291-305.

Amin, M.R., M.K. Hasa, Q. Naher, M.A. Hossain, and Z.U. Noor. 2007. Response of onion to NPKS fertilizers in low ganges river flood plain soil. Intl. J. Sustainable Crop Production 2:11-14.

Bary, A.I., C.G. Cogger, and D.M. Sullivan. 2000. Fertilizing with manure. Washington State Univ. Coop. Ext., Pacific Northwest Ext. Publ. 533.

Bevacqua, R.F. and V.J. Mellano. 1993. Sewage sludge compost's cumulative effects on crop growth and soil properties. Compost Sci. Util. 1:34-40.

Biberacher, M., S. Warnecke, H.J. Brauckmann, and G. Broll. 2009. A linear optimization model for animal farm manure transports in regions with high intensity animal farming. 18th World Intl. Mathematics and Computers in Simulation (IMACS)/Modeling and Simulation (MOSIM) Congr., Cairns, Australia. p. 470-476.

Boyhan, G.E. 2007. Effects of nitrogen, phosphorus, and potassium rates and fertilizer sources on yield and leaf nutrient status of short-day onions. HortScience 42:653-660.

Boyhan, G.E., R.J. Hicks, R.L. Torrance, C.M. Riner, and R. Hill. 2010. Evaluation of poultry litter and organic fertilizer rate and source for production of organic intermediate-day onions. HortTechnology 20:304-307.

Brewster, J.L. 2008. Onions and other vegetable alliums. 2nd ed. CABI. Wallingford, UK.

Brown, B. 2000. Southern Idaho fertilizer guide: Onions. Coop. Ext. System Agr. Expt. Sta., Univ. Idaho CIS1081.

Dauda, S.N., F.A. Ajayi, and E. Ndo. 2008. Growth and yield of water melon (Citrullus lanatus) as affected by poultry manure application. J. Agr. Soc. Sci. 4:121-124.

El-Al, F.S.A., A.M. Shaheen, F.A. Rizk, and M.M. Hafez. 2010. Influence of irrigation intervals and potassium fertilization on productivity and quality of onion plant. Intl. J. Academic Res. 2:110-116. 
El-Bassiony, A.M. 2006. Effect of potassium fertilization on growth, yield and quality of onion plants. J. Appl. Sci. Res. 2:780-785.

Gallardo-Lara, F. and R. Nogales. 1987. Effect of the application of town refuse compost on the soil-plant system: A review. Biol. Wastes 19:35-62.

Gambo, B.A., M.D. Magaji, A.I. Yakubu, and A.U. Dikko. 2008. Effects of farmyard manure, nitrogen and weed interference on the growth and yield of onion (Allium cepa L.) at the Sokoto Rima Valley. J. Sustainable Dev. Agr. Environ. 3:87-92.

Gaskell, M. and R. Smith. 2007. Nitrogen sources for organic vegetable crops. HortTechnology 17:431-441.

Gericke, S. and B. Kurmies. 1952. The colorimetric phosphorus analysis with ammonium-vandate-molybdate and its application in plant analysis. Plant Fert. Soil 59:235-247.

Greenwood, D.J., A. Gerwitz, D.A. Stone, and A. Barnes. 1982. Root development of vegetable crops. Plant Soil 68:75-96.

Haynes, R.J. and R. Naidu. 1998. Influence of lime, fertilizer and manure applications on soil organic matter content and soil physical condition: A review. Nutr. Cycl. Agroecosyst. 51:123-137.

Lee, J. 2010. Effect of application methods of organic fertilizer on growth, soil chemical properties and microbial densities in organic bulb onion production. Sci. Hort. 124:299-305.

Lee, J.T., I.J. Ha, H.D. Kim, J.S. Moon, and S.D. Lee. 2009. Times and frequencies of additional fertilization to improve nutrient efficiency of organic liquid fertilizer for onion organic cultivation. Korean J. Hort. Sci. Technol. 27:30-36.

Lee, J.T., I.J. Ha, C.J. Lee, J.S. Moon, and Y.C. Cho. 2003. Effect of N, $\mathrm{P}_{2} \mathrm{O}_{5}$, and $\mathrm{K}_{2} \mathrm{O}$ application rates and top dressing time on growth and yield of onion (Allium cepa L.) under spring culture in low land. Korean J. Hort. Sci. Technol. 21:260-266.

Palm, C.A., C.N. Gachengo, R.J. Delve, G. Cadisch, and K.E. Giller. 2001. Organic inputs for soil fertility management in tropical agroecosystems: Application of an organic resource database. Agr. Ecosyst. Environ. 83:27-42.

Portas, C.A.M. 1973. Development of root systems during the growth of some vegetable crops. Plant Soil 39:507-518.

Prasad, M. 2009. A literature review on the availability of nitrogen from compost in relation to the nitrate regulations SI 378 of 2006. EPA STRIVE Programme 2007-2013. Small Scale Study Rpt., Environmental Protection Agency, Johnstown Castle, Ireland.

Rathod, P.H., J.C. Patel, M.R. Shah, and A.J. Jhala. 2008. Recycling gamma irradiated sewage sludge as fertilizer: A case study using onion (Alium cepa). Appl. Soil Ecol. 41:223-233.

Rosen, C.J. and D.L. Allen. 2007. Exploring the benefits of organic nutrient sources for crop production and soil quality. HortTechnology 17:422-430.

Rural Development Administration. 2002. Methods of soil and plant analysis (in Korean). Natl. Inst. Agr. Sci. Technol., Suwon, Korea.

Rural Development Administration. 2006. The standard of fertilizer application on crop species (in Korean). Natl. Inst. Agr. Sci. Technol., Suwon, Korea.

Salo, T., T. Suojala, and M. Kallela. 2002. The effect of fertigation on yield and nutrient uptake of cabbage, carrot and onion. Acta Hort. 571:235-241.

Schollenberger, C.J. 1927. A rapid approximate method for determining soil organic matter. Soil Sci. 24:65-68.

Sullivan, D.M., B.D. Brown, C.C. Shock, D.A. Horneck, R.G. Stevens, G.Q. Pelter, and E.B.G. Feibert. 2001. Nutrient management for onions in the Pacific Northwest. Oregon State Univ., Washington State Univ., Univ. of Idaho, Pacific Northwest Ext. Publ. 546.

Suresh, K.D., G. Sneh, K.K. Krishn, and C.M. Mool. 2004. Microbial biomass carbon and microbial activities of soils receiving chemical fertilizers and organic amendments. Arch. Agron. Soil Sci. 50:641-647.

Vidigal, S.M., M.A.N. Sediyama, M.W. Pedrosa, and M.R. Santos. 2010. Onion yield in organic system using compost of swine manure. Horticultura Brasileira 28:168-173

Wallace, P. 2006. Production of guidelines for using compost in crop production: A brief literature review. Project Code ORG 0036. WRAP, Banbury, UK.

Weaver, J.E. and W.E. Brunner. 1927. Root development of vegetable crops. McGraw-Hill, New York, NY. 